\title{
Experiential Learning in Metrology and Quality Engineering Course
}

\author{
N.Vijayakumar ${ }^{1}$, V.N.Gaitonde ${ }^{2}$, A.R. Lakkundi ${ }^{3}$, H.K. Madhusudhana ${ }^{4}$, Jangali Satish $\mathbf{G}^{5}$ \\ 1,2,3,4 Department of Industrial\& Production Engineering \\ B.V.B. College of engineering \& Technology, Hubli-580 031, Karnataka, India

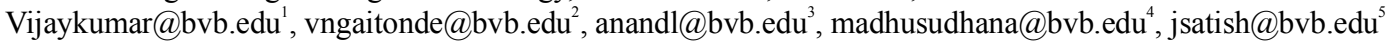

\begin{abstract}
Technical education programs have embraced experiential learning as a true learning methodology for students to obtain occupational skills valued by employers. Programs have integrated classroom instruction with laboratory experiences to provide students a significant opportunity to learn. A fundamental component in professional education is the link between theory and practice. However, many students in professional education programs experience a lack of coherence between theory and practice, which is often described as the theory practice gap. This work is a part of "Bridging the Gap" in metrology and quality engineering course, designed for the undergraduate students of VI Semester Industrial and Production Engineering of BVBCET, Hubli, an autonomous institute. Two problem statements were given to the students; one was on the process capability analysis of machines and another on the construction of control chart for variables, which they have to solve after conducting the experiments in machine shop in batches. The students had to chalk out the necessary information to conduct the experiment like profile, sample size,
\end{abstract}

\section{N.Vijayakumar}

Department of Industrial\& Production Engineering

B.V.B. College of engineering \& Technology, Hubli-580 031,

Karnataka, India

Vijaykumar@bvb.edu subgroup size and finally analyze the experimental data to decide whether machine is capable to meet the specifications of part and detect the presence of assignable or un assignable causes of variation using process capability analysis and control chart respectively. After the completion of this exercise, the students could realize the importance of process capability analysis and control charts in the manufacturing industries. This activity was step forward in bridging the gap between theory and lab through experiential learning. The performance indicators (PIs) of the ABET program outcome ' $3 \mathrm{~b}$ ' were underlying the motivators while designing the present experiential learning activity.

Keywords- Experiential learning, process capability, Control chart, Performance indicator, Assessment rubrics.

\section{Introduction}

\section{"IHEARANDIFORGET \\ I SEE AND I REMEMBER IDOAND I UNDERSTAND".}

This quote by Confucius is attributed to express conviction that experiential learning is effective [1].

Rogers defined the essence of experiential learning as [1]:

"It has a quality of personal involvement-the whole-person in both his feeling and cognitive aspects being in the learning event." 
Hoover states that [1],

"Experiential learning exists when a personally responsible participant cognitively, affectively and behaviorally processes knowledge, skills and/or attitudes in a learning situation characterized by a high level of active involvement".

The following are the critical components of the experiential learning [1]:

A. Applied: As presented by Wolfe and Byrne [1], the design phase of the experience is critical. Experiences occurring without the guidance and adequate academic preparation may yield little insight into the general processes taking place. The experience will not qualify as applied experiential learning without having the expected educational outcomes articulated and related to the curriculum

B. Participative: The student must be involved in the process. Experiential learning is active rather than passive. Rather than just listening to a lecture, students do role-plays, or make decisions (as in a simulation game), or perform an analysis of a firm's problems (as in a small business case project).

C. Interactive: The interaction involves more than just the instructor/student, student/student, student/client or student/environment interaction is also required. Example interactions include group decision-making in simulation game, presentations to clients in small business case projects, and conducting survey research of local households for a marketing research course project.

Bridging the gap between theory and practice in professional education programs' is a new challenge. Overcoming the perceived gap between theory and practice in pre-service professional education has been attempted by many. Today, the dominating view is that theory and practice should be integrated. The concept of a theory-practice gap dominates approaches to preparing professionals for their future role. With increasing emphasis on work-based learning one of the many strategies designed to support students and professionals is supervision.

An attempt has been made in this paper to bridge the gap between theory and practice through an Experiential Learning in the course "Metrology and Quality Engineering Lab" for undergraduate students of VI Semester Industrial and Production Engineering. Before this initiative, faculty used to teach the concept of process capability and control chart in traditional way through the class room teaching, where in the students had to visualize the application of the concept in an industry. Through this work students are actually involved in conducting the process capability and control chart study as in an industrial environment.

Process Ccapability Study (PCS): PCS is a scientific and systematic procedure that uses control charts to detect and eliminate the unnatural causes of variation until a state of statistical control is reached [2].

When the study is completed, it will identify the natural variability of the process. Process-capability analysis is a technique applied in many stages of the product cycle, including process, product design, manufacturing and manufacturing planning, since it helps to determine the ability to manufacture parts within the tolerance limits and engineering values. There are several capability indices [3,4] including CP, CPU, CPL and CPk. (Table I) that have been widely used in the manufacturing industry to provide common quantitative measures of process potential and performance.

Figure 1 shows the spread of process from mean of, where: USL = Upper Specification Limit, LSL = Lower Specification Limit, = Mean of the process and ? = Standard deviation of the Process. Any product dimensions falls above the upper specification limit are to be reworked and the product dimension falls below lower specification limit are to be treated as scrap.

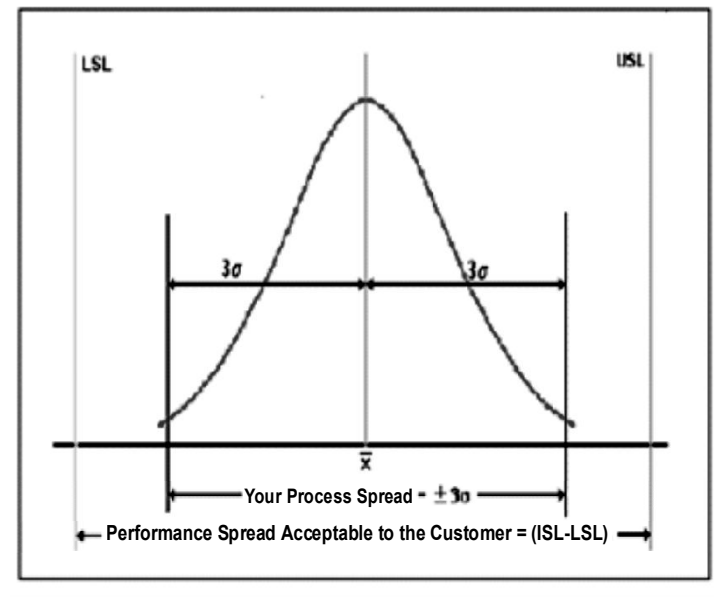

Fig. 1. Spread of the process

The defect levels or parts per million nonconforming were computed for different $\mathrm{CPk}$ values using the $\mathrm{Z}$ scores and the percentage area under the 
standard normal curve using normal deviate tables.

Table 1 Equations Quantifying Process Capability $[3,4]$
The capability of process to meet the specifications can be analyzed by determining the value of $\mathrm{Cp}$ and $\mathrm{CPk}$, which is shown in Table II.

Table 2 Process Capability Index Values

\begin{tabular}{|c|l|}
\hline $\begin{array}{c}\text { Capability } \\
\text { index }\end{array}$ & \multicolumn{1}{c|}{ Estimation of the process } \\
\hline $\mathrm{C}_{\mathrm{Pk}}=\mathrm{C}_{\mathrm{p}}$ & $\begin{array}{l}\text { Process is placed exactly at the centre of } \\
\text { the specification limits. }\end{array}$ \\
\hline $\mathrm{C}_{\mathrm{p}}<1$ & Process is not capable. \\
\hline $\mathrm{C}_{\mathrm{p}}, \mathrm{C}_{\mathrm{Pk}}>1$ & Process is capable \\
\hline $\mathrm{Cp}_{\mathrm{p}} \geq 1.33$ & Process is satisfactory enough. \\
\hline $\mathrm{C}_{\mathrm{p}} \geq 1.66$ & Process is very satisfactory. \\
\hline
\end{tabular}

Control chart: Variation is present in every process due to a combination of the equipment, materials, environment and operator. There are two causes for variation; one is assignable and another is unassignable cause or chance cause. The control chart is a graphical and analytical tool used to decide whether a process is prevailing with unassignable causes of variations (Figure 2). A process that is operating with only unassignable causes of variation is said to be in statistical control. A process that is operating with assignable causes is said to be out of control.

A typical pattern of variation in process is represented in Figure 2.

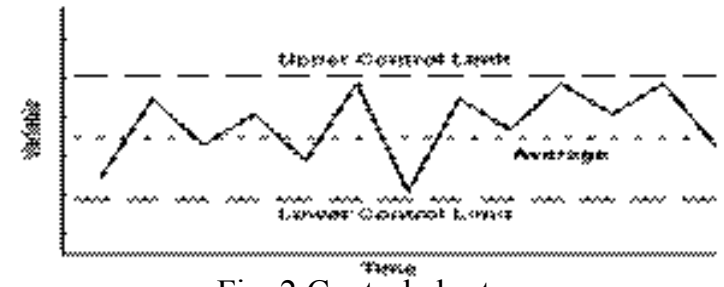

Fig. 2.Control chart

\section{Objectives}

The overall objective of this experiment is to build the competency among the students towards solving industrial quality related issues. The specific objectives are as follows:

1. To help the students to acquire deeper understanding of the subject concept.

2. To develop the capacity for critical thinking and apply the knowledge in complex or ambiguous situations.

3. To engage in lifelong learning including learning in the workplace.

4. To design, collect data, organize, analyze and interpret the experimental results.

\section{Methodology}

The activity started with the formation of two groups in each practical batch. One group was assigned with the problem on process capability analysis of machines and other on the construction of control chart for variables and these two problems and they have to carry out these activities in the machine shop using lathe machine; the experimental setup is shown in Figure 3. Before the commencement of the activity, the students were asked to design the experiment by selecting appropriate subgroup size, sample size, profile and the type of operation before the manufacturing of component profile. They have selected the step turning operation for conducting the process capability analysis and control chart. The profile for studying process capability and control chart is shown in in Figure 4. While deciding the profile, the students used the concept of optimization of resources (minimum usage of material) i.e. they have designed the profile in such a way that four dimensions accommodated in a single part. A subgroup size of 5 and 4 samples in each subgroup were selected. The component was machined and the dimensions of the product were measured. The experimental data of this activity is illustrated in Table III and Table IV for the process capability and control chart respectively. Using these results, the students analyzed the data using MINITAB statistical software [5] and concluded the capability of the process and the presence of assignable or unassignable causes of variation. Each batch presented their findings in front of the faculty member and the assessment was done for the attainment of ABET program outcome ' $3 \mathrm{~b}$ ' through assessment rubrics. 
Fig. 3. Lathe machine used for the process capability and control chart study

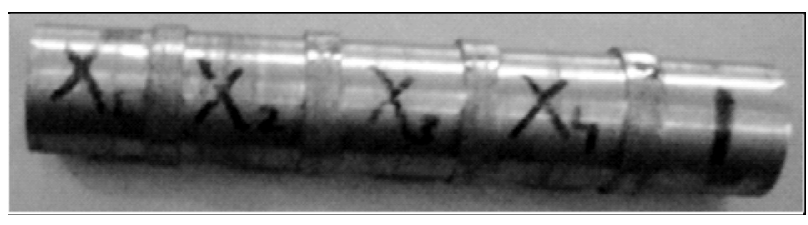

Fig. 4. Profile for studying process capability and control chart

\section{Results And Discussion}

The details of the activity carried out by the students are presented below:

\section{A. Process Capability Analysis in Turning Operation}

The process capability analysis performed by the students in a machine shop on lathe machine has been presented in this section. The focus of the study was to investigate the ability of the process to meet the customer specification requirement in machining (step turning) on lathe machine. A group of 8 students carried out the machining operation using a lathe machine; a sufficient number of samples (20 nos.) were turned to achieve a target dimension. Accordingly, the dimensions of each component were measured and collected data was then analyzed using MINITAB software to know the process capability indices. The experimental data for the process capability study is shown in Table III and the process capability experimental details are as follows:

Machine used: Tool room lathe

Tool material: Single point carbide

Work piece material: Mild steel.

Diameter of a raw material $\quad=25 \mathrm{~mm}$
The required target diameter $=22 \mathrm{~mm}$

Tolerance selected for turning $\quad= \pm 1 \mathrm{~mm}$

Table 3 Experimental Data For Process Capability

\begin{tabular}{|c|c|c|c|c|c|c|}
\hline $\begin{array}{c}\text { Sub } \\
\text { group }\end{array}$ & $\mathbf{X}_{\mathbf{1}}$ & $\mathbf{X 2}$ & $\mathbf{X 3}$ & $\mathbf{X 4}$ & $\overline{\mathrm{X}}$ & $\mathrm{R}$ \\
\hline 1 & 22.1 & 22.02 & 21.82 & 21.70 & 21.91 & 0.4 \\
\hline 2 & 21.86 & 22.77 & 21.82 & 21.88 & 22.1 & 0.95 \\
\hline 3 & 22.02 & 21.80 & 22.10 & 22.88 & 222 & 1.08 \\
\hline 4 & 21.6 & 21.76 & 22.00 & 22.10 & 21.9 & 0.5 \\
\hline 5 & 22.0 & 21.80 & 21.90 & 21.82 & 21.9 & 0.2 \\
\hline
\end{tabular}

$\mathrm{x}_{1}, \mathrm{x}_{2}, \mathrm{x}_{3}$ and $\mathrm{x}_{4}$ are the dimensions of the samples .

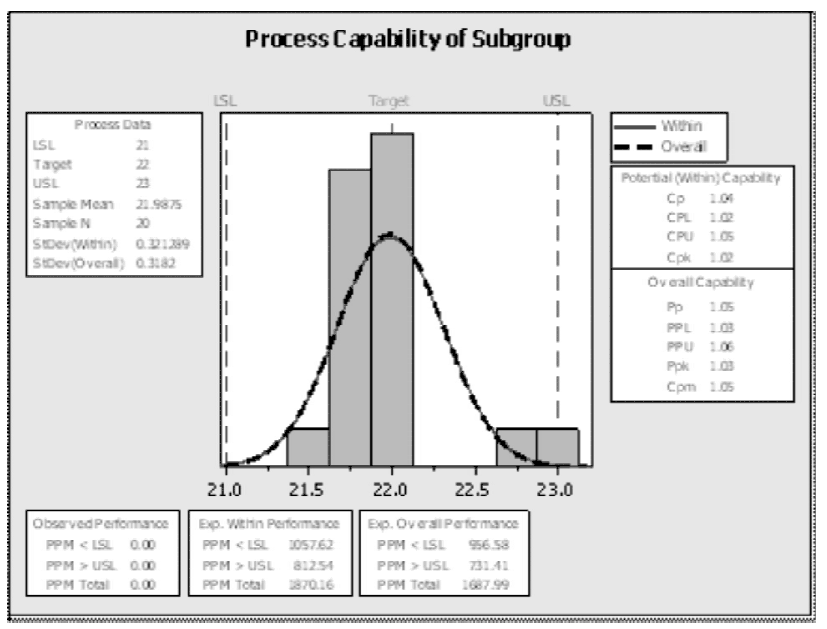

Fig. 5. Process capability analysis

Figure 5 depicts the process capability analysis. The indices $\mathrm{CP}$ and $\mathrm{CPk}$ for the process capability study are 1.04 and 1.02 respectively.

Inference: Since both $\mathrm{CP}$ and $\mathrm{CPk}>1$; the process is capable of meeting the specification limits.

B. Analyzing the presence of assignable and unassignable causes of variation using control chart in turning operation on lathe machine

Here, the students performed step turning operation for 5 subgroups to the required diameter and sample of 4 in each subgroup was selected; the data is shown in Table IV. The data was then analyzed using MINITAB software and the and R charts for the results are shown in Figure 6 and Figure 7 respectively. 
Table 4 Experimental Data For Control Chart

\begin{tabular}{|c|c|c|c|c|c|c|}
\hline $\begin{array}{c}\text { Sub } \\
\text { group }\end{array}$ & $\mathbf{S}_{\mathbf{1}}$ & $\mathbf{S}_{\mathbf{2}}$ & $\mathbf{S}_{\mathbf{3}}$ & $\mathbf{S}_{\mathbf{4}}$ & $\overline{\mathrm{X}}$ & $\mathrm{R}$ \\
\hline 1 & 21 & 21.13 & 21.36 & 21.22 & 21.177 & 0.36 \\
\hline 2 & 21.12 & 21.24 & 21.2 & 21.3 & 21.215 & 0.18 \\
\hline 3 & 20.86 & 21.36 & 21.3 & 21.14 & 21.165 & 0.5 \\
\hline 4 & 21.32 & 21.41 & 22 & 21.34 & 21.517 & 0.68 \\
\hline 5 & 21.06 & 21.18 & 21.28 & 21.25 & 21.192 & 0.22 \\
\hline \multicolumn{7}{|c|}{$\mathrm{S}_{1}, \mathrm{~S}_{2}, \mathrm{~S}_{3}$ and $\mathrm{s}_{4}$ are the samples } \\
\hline
\end{tabular}

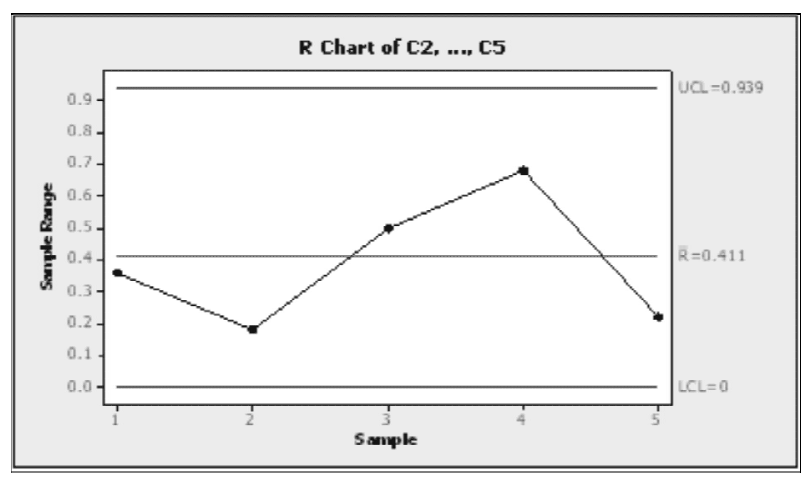

Fig. 6. $\overline{\mathrm{X}}$-chart

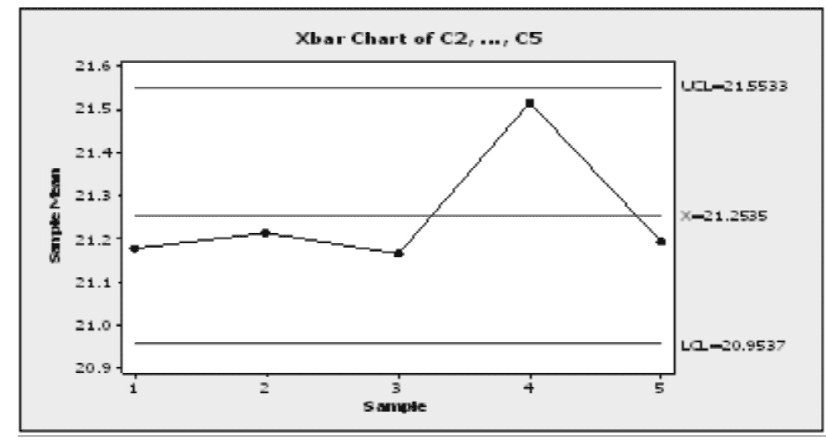

Fig. 7. R- chart

Inference: From Figures 6 and 7 of control charts, it was observed that all the points are within the control limits and hence the process is prevailing with unassignable causes of variation and statistically within control.

Assessment: Assessment was done for the attainment of ABET program outcome ' $3 \mathrm{~b}$ '. The performance indicators (PIs) defined for the outcomes are as follows:

i. Design an experiment to verify the conceptual understanding.

ii. Conduct an experiment and report the results.

iii. Analyze the experimental results. iv. Interpret the experimental data.

Students were evaluated for each of the indicators through demonstration, presentation and viva-voce examination assessed through rubrics (shown in Appendix). The attainment for each of the PIs of ' $3 b^{\prime}$ outcome was recorded. Figure 8 presents the overall attainment of the program outcome ' $3 b$ ' and Figure 9 gives the attainment of each indicator. The overall class attainment for the program outcome ' $3 b$ ' is $88.77 \%$.

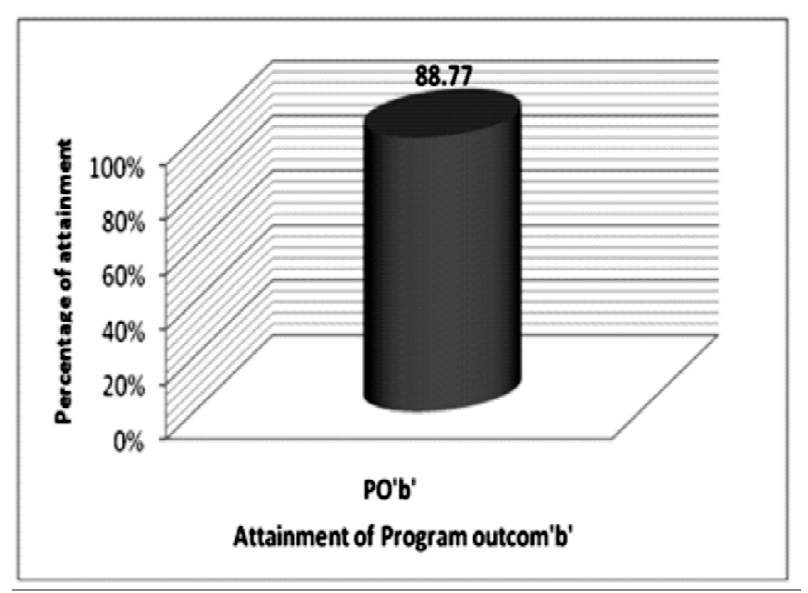

Fig. 8. Attainment of Program Outcome ' $3 b^{\prime}$

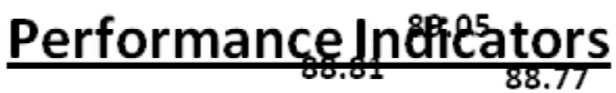

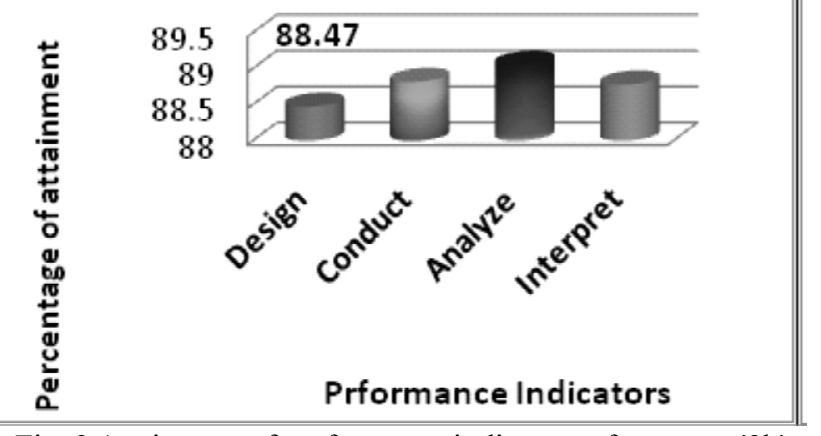

Fig. 9 Attainment of performance indicators of outcome ' $3 b$ '.

\section{Conclusion}

Before the initiation of this activity, the students were used to learnt only the concepts of process capability and the control charts in passive mode of learning i.e. classroom teaching. However, the experiential learning exercise adopted in metrology and quality-engineering course for Industrial and Production Engineering undergraduate program really helped the students not only in acquiring deeper understanding of the concepts but also they learnt how to practice these concepts to a greater extent in a real life situation in particular in industry. In addition, the 
activity also helped the faculty in bridging the gap between theory and practice. Through, this activity, the program outcome ' $3 b$ ' has been addressed through identified performance indicators (PIs).

\section{Acknowledgment}

The authors would like to thank Dr. Ashok Shettar Principal and Dr. B.B. Kotturshettar, Professor and Head, Department of Industrial \& Production Engineering, BVBCET, Hubli for their continuous guidance and motivation for this innovative practice. Authors also thank Instructors of Machine shop as well as Metrology and Quality Engineering lab for their constant support during the execution of this activity.

\section{References}

[1] Gentry JW (1990) Guide to Business Gaming and Experiential Learning,.

[2] Boyles RA (1994). Process capability with symmetric tolerances. Commun. StatisticsSimul. Comput. 23(3): 615-643.

[3] Ramakrishnan B, Sandborn P, Pecht M. (2001). Process capability indices and product reliability. Microelectronics Reliability 41, 2067-2070.

[4] Kane,VE. Process capability indices. Journal of Quality Technology 18(1986), 41-52.

[5] Minitab Inc. (2011) Minitab User Manual Version 16, Quality Plaza, 1829 Pine Hall Road, State College, PA 16801-3008, USA.

\begin{tabular}{|c|c|c|c|c|c|}
\hline Performance Indicator & Measure & $\begin{array}{l}0.25 \% \\
(1)\end{array}$ & $\begin{array}{l}26-50 \% \\
(2)\end{array}$ & $\begin{array}{l}51-75 \% \\
(3)\end{array}$ & $\begin{array}{c}76-100 \% \\
(4)\end{array}$ \\
\hline \multirow{3}{*}{ Design an experiment } & $\begin{array}{l}\text { 1.Define goal and objectives of the } \\
\text { experiment }\end{array}$ & $\begin{array}{l}\text { Incapable of defining objective } \\
\text { of experiment }\end{array}$ & $\begin{array}{l}\text { Some understanding of objective } \\
\text { of experiment }\end{array}$ & $\begin{array}{l}\text { Overall sound understanding of } \\
\text { objective of experiment, subgroup } \\
\text { size, sample size, method of collection } \\
\text { of data. Does not significantly impair } \\
\text { solution }\end{array}$ & $\begin{array}{l}\text { Clear and complete understanding } \\
\text { objective of experiment, subgroup } \\
\text { size, sample size, method of } \\
\text { collection of data }\end{array}$ \\
\hline & $\begin{array}{l}\text { 3.Select appropriate method, choose } \\
\text { equipment and instrumentation }\end{array}$ & $\begin{array}{l}\text { Incapable of selecting method } \\
\text { of collection of data, }\end{array}$ & $\begin{array}{l}\text { Capable choosing correct } \\
\text { method of collection of data }\end{array}$ & $\begin{array}{l}\text { Overall sound understanding and } \\
\text { choosing appropriate equipment and } \\
\text { collecting correct data }\end{array}$ & $\begin{array}{l}\text { Clear and complete understanding } \\
\text { method of collection of data. }\end{array}$ \\
\hline & $\begin{array}{l}\text { 4.Determine the appropriate number of } \\
\text { data points }\end{array}$ & $\begin{array}{l}\text { Incapable of determining } \\
\text { number of data points }\end{array}$ & $\begin{array}{l}\text { Able to determining number of } \\
\text { data points }\end{array}$ & $\begin{array}{l}\text { Collecting acceptable number of data } \\
\text { points }\end{array}$ & Collected exact number of data points \\
\hline \multirow[t]{3}{*}{ Conduct } & 2.Calibrate the instruments to be used & $\begin{array}{l}\text { In capable of Inspecting the } \\
\text { calibrated instruments }\end{array}$ & $\begin{array}{l}\text { Some deficiencies in inspection } \\
\text { (calibration) }\end{array}$ & $\begin{array}{l}\text { Overall sound understanding in using } \\
\text { calibrated instrument }\end{array}$ & $\begin{array}{l}\text { Clear and complete understanding in } \\
\text { using calibrated instrument }\end{array}$ \\
\hline & $\begin{array}{l}\text { 3.Follow the proper procedure to collect } \\
\text { the data }\end{array}$ & $\begin{array}{l}\text { Improper procedure adopted } \\
\text { for data collection. }\end{array}$ & $\begin{array}{l}\text { Marginally acceptable procedure } \\
\text { adopted for collection of data. }\end{array}$ & $\begin{array}{l}\text { Overall sound understanding the } \\
\text { procedure of data collection }\end{array}$ & $\begin{array}{l}\text { Clear and complete understood the } \\
\text { proper procedure for data collection. }\end{array}$ \\
\hline & $\begin{array}{l}\text { 4. Measure the performance of the } \\
\text { product/process }\end{array}$ & $\begin{array}{l}\text { Inadequate measurement of } \\
\text { the performance of } \\
\text { product/process }\end{array}$ & $\begin{array}{l}\text { Marginally adequate } \\
\text { measurement of the } \\
\text { product/process performance }\end{array}$ & $\begin{array}{l}\text { Overall sound understanding measure } \\
\text { of the process performance }\end{array}$ & $\begin{array}{l}\text { Satisfactorily measured of the process } \\
\text { performance }\end{array}$ \\
\hline \multirow{3}{*}{ Analyze data } & 1. Carry out the necessary calculations. & $\begin{array}{l}\text { Serious deficiencies in } \\
\text { understanding the correct } \\
\text { selection and/or use of tools } \\
\text { for analyzing data }\end{array}$ & $\begin{array}{l}\text { Minimal ability to conduct } \\
\text { calculations }\end{array}$ & $\begin{array}{l}\text { Overall acceptable in carrying out the } \\
\text { necessary calculations }\end{array}$ & $\begin{array}{l}\text { Clear understanding in carrying out } \\
\text { the necessary calculations }\end{array}$ \\
\hline & 2.Perform an error analysis & $\begin{array}{l}\text { Serious deficiencies in } \\
\text { understanding and using } \\
\text { correct tools for analyzing data }\end{array}$ & $\begin{array}{l}\text { Minimal application and use of } \\
\text { appropriate tools for analyzing } \\
\text { the collected data }\end{array}$ & $\begin{array}{l}\text { Moderately acceptable in performing } \\
\text { an error analysis }\end{array}$ & $\begin{array}{l}\text { Satisfactorily performed error } \\
\text { analysis }\end{array}$ \\
\hline & $\begin{array}{l}\text { 3.Tabulate and plot the results using } \\
\text { appropriate choice of variables and } \\
\text { software }\end{array}$ & $\begin{array}{l}\text { Serious deficiencies in } \\
\text { understanding of tabulation } \\
\text { and plots of results. }\end{array}$ & $\begin{array}{l}\text { Minimal ability of } \\
\text { tabulation/plotting results using } \\
\text { appropriate choice of software }\end{array}$ & $-\quad \ldots$ & $\begin{array}{l}\text { Computer-aided tools are used } \\
\text { effectively to develop and analyze } \\
\text { collected data. }\end{array}$ \\
\hline \multirow[b]{2}{*}{ Interpret data } & $\begin{array}{l}\text { 1.Make observations and draw } \\
\text { conclusions regarding the variation of } \\
\text { the parameters involved }\end{array}$ & $\begin{array}{l}\text { Incapable of interpreting the } \\
\text { analysis of data }\end{array}$ & $\begin{array}{l}\text { Serious deficiencies in } \\
\text { interpretation the data analysis }\end{array}$ & $\begin{array}{l}\text { Some understanding of interpretation } \\
\text { the analysis of data. }\end{array}$ & $\begin{array}{l}\text { Clear and complete understanding of } \\
\text { the interpretation of analyzed data }\end{array}$ \\
\hline & $\begin{array}{l}\text { 2. Compare with predictions from } \\
\text { theory or design calculations and } \\
\text { explain any discrepancies. }\end{array}$ & $\begin{array}{l}\text { Incapable making predictions } \\
\text { for future course of action to } \\
\text { control the process }\end{array}$ & $\begin{array}{l}\text { Serious deficiencies observed in } \\
\text { predicting future course of } \\
\text { action to control the process }\end{array}$ & $\begin{array}{l}\text { Some understanding on } \mathrm{i} \text { nterpreting } \\
\text { the analyzed data and make } \\
\text { predictions for future course of action } \\
\text { to control the process }\end{array}$ & $\begin{array}{l}\text { Satisfactorily analyzed the data and } \\
\text { has made predictions for future course } \\
\text { of action to control the process }\end{array}$ \\
\hline
\end{tabular}

